\title{
Article \\ Sheep Dung Ash as a Low-Cost Adsorbent for the Reduction of COD of Highly Polluted Oilfield-Produced Water
}

\author{
Ahmed M. Abbas ${ }^{1,2}{ }^{\mathbb{D}}$, Sayed M. Abboudy ${ }^{3}$ and Adel Abdelkader ${ }^{3, *}$ \\ 1 Biology Department, College of Science, King Khalid University, Abha 61413, Saudi Arabia; \\ ahhassan@kku.edu.sa \\ 2 Department of Botany \& Microbiology, Faculty of Science, South Valley University, Qena 83523, Egypt \\ 3 Chemistry Department, Faculty of Science, South Valley University, Qena 83523, Egypt; \\ sayed_abboudy78@yahoo.com \\ * Correspondence: adel.abdelkader@sci.svu.edu.eg; Tel.: +20-101-812-1041
}

check for updates

Citation: Abbas, A.M.; Abboudy, S.M.; Abdelkader, A. Sheep Dung Ash as a Low-Cost Adsorbent for the Reduction of COD of Highly Polluted Oilfield-Produced Water. Water 2022, 14, 434. https://doi.org/10.3390/ w14030434

Academic Editor: Ignacio de Godos

Received: 9 December 2021

Accepted: 27 January 2022

Published: 31 January 2022

Publisher's Note: MDPI stays neutral with regard to jurisdictional claims in published maps and institutional affiliations.

Copyright: (c) 2022 by the authors. Licensee MDPI, Basel, Switzerland. This article is an open access article distributed under the terms and conditions of the Creative Commons Attribution (CC BY) license (https:// creativecommons.org/licenses/by/ $4.0 /)$.

\begin{abstract}
Herein, we introduce a low-cost, available, renewable, and effective solid adsorbent used for oilfield-produced-water treatment using a straightforward treatment process. In the present study, sheep dung ash was prepared using the same way this waste is produced in rural areas when sheep dung is used as a source of energy for cooking and heating: by burning sheep dung with a direct flame. The prepared ash was characterized using FTIR, EDX, and SEM analysis techniques. The feasibility of the ash as a low-cost, available, renewable, and effective adsorbent for reducing the COD of oilfield-produced water with the initial COD of $21,600 \mathrm{mg} / \mathrm{L}$ was investigated. The effect of adsorbent dose, contact time (in hours and days), initial $\mathrm{pH}$ value, and initial COD value on the efficiency of sheep dung ash in COD adsorption was examined at room temperature. With shaking, the maximum capacity of sheep dung ash for COD reduction was found to be $71.8 \%$ at an adsorbent dosage of $30 \mathrm{~g} / \mathrm{L}$, an initial $\mathrm{pH}$ of 7 , and a contact time of $1 \mathrm{~h}$. Without shaking, a maximum capacity of $75 \%$ for COD reduction was obtained at an adsorbent dosage of $30 \mathrm{~g} / \mathrm{L}$, an initial $\mathrm{pH}$ of 7 , and a contact time of 4 days. By applying the experimental results on Langmuir and Freundlich models of adsorption, it was found that the adsorption process of COD causing molecules follows both Langmuir and Freundlich models.
\end{abstract}

Keywords: adsorption; chemical oxygen demand; bio-waste; produced water; sheep dung ash

\section{Introduction}

There is no doubt that water is the basis of our life, and securing water sources is the most critical human demand. The treatment of wastewater is one of the fundamental ways to ensure water source availability, especially in countries that lack natural water sources. Produced water is one of the essential types of wastewaters produced in large quantities worldwide. It is water trapped in underground formations and represents the largest volume of by-product extracted to the surface from oil and gas [1]. The physical and chemical properties of produced water depend on many factors, including the field's geographic location, the age and depth of the geological formation, hydrocarbon-bearing formation geochemistry, and the method of extraction, in addition to the type and chemical composition of the produced hydrocarbon [2]. In the oilfields, the wells' normal water-to-oil ratio is in the range of 3 to $4(v / v)$. However, the water content reaches over $98 \%$ for some wells in the late or end period of oil extraction [3]. Due to the aging of wells worldwide, the average water-to-oil ratio is expected to reach $12(v / v)$ by 2025 [2]. The daily global production of produced water now is around 250 million barrels. Greater than $40 \%$ is discharged to the environment, making it one of the most significant contributors to environmental pollution $[4,5]$. The discharge of untreated produced water into the surrounding environment causes severe pollution of surface, soil, and underground water [5]. The primary sources of pollution in produced water are dissolved oil, polyaromatic hydrocarbons, 
production chemical compounds, total dissolved solids, heavy metals, and radioactive materials [4]. The presence of these pollutants in produced water is the reason for the increased toxicity, chemical oxygen demand (COD), biological oxygen demand (BOD), and turbidity of produced water [4]. Due to the need for new water sources and the strictness of effluent discharge quality standards, it has become necessary to find solutions to treat these large quantities of polluted water to be reused or disposed of without polluting the environment [6]. The main methods used to treat produced water are physical treatment, chemical treatment, biological treatment, membrane treatment, and advanced oxidation processes [7]. As one of the physical treatment methods, adsorption has many advantages over the other techniques that make it the best choice for produced water treatment. The benefits of the adsorption method compared to the other techniques include low cost, ease of operation, simplicity of the used design, insensitivity to toxic materials, possibility of recovery of the adsorbed materials, and the regeneration of adsorbents easily by different methods [5,8]. Due to the high cost of the commercially available adsorbents, efforts have been made to develop low-cost adsorbents for the treatment of produced water [9]. In a previous study [8], we recovered a high surface area of boehmite nanopowder from waste aluminum cans to be used as a low-cost adsorbent to remove COD from oilfield-produced water (initial COD $=1150 \mathrm{mg} / \mathrm{L}$ ). The maximum capacity of the prepared boehmite for COD reduction was $69.6 \%$ at an adsorbent dosage of $40 \mathrm{~g} / \mathrm{L}$, an initial $\mathrm{pH}$ value of 7 , and a contact time of $24 \mathrm{~h}$.

The ashes produced due to biomass combustion are low-cost adsorbents that may be applied to treat produced water. These ashes have the advantages of being renewable, low cost, and available in considerable amounts in most rural areas across the world. It is essential to know that biomass combustion does not contribute to global warming since the same amount of $\mathrm{CO}_{2}$ released during biomass combustion is extracted from the air during the growth period of the plants [10]. One of the essential types of ashes is sheep dung ash, a common by-product produced daily in large amounts after dry sheep dung is burned for heating and cooking in the rural areas in Egypt and other countries. To the best of our knowledge (acquired after a detailed review of literature), there is no study about using sheep dung ash as an adsorbent to remove COD from produced water. Therefore, this study aims to explore the feasibility of using sheep dung ash as a low-cost available and renewable adsorbent for COD adsorption from highly polluted produced water (COD $=21,600 \mathrm{mg} / \mathrm{L}$ ) from an Egyptian oilfield and to compare the maximum \% COD removal by sheep dung ash with that by other adsorbents.

\section{Materials and Methods}

\subsection{Preparation of Sheep Dung Ash}

The dry sheep dung biomass was received from a private farm in Elbayadia village in Qena city in southern Egypt. To reduce production cost and simulate reality, the ash was prepared in the same way it is produced in the Egyptian rural areas while using biomass for heating and cooking. As shown in Figure 1, about $1 \mathrm{~kg}$ of dry sheep dung biomass was placed inside a large steel container and then burned in the open air using a direct flame. The burned sheep dung was left overnight in the open air to complete the combustion process. The resultant ash was allowed to cool to room temperature and stored in a closed plastic bottle (Figure 1). 


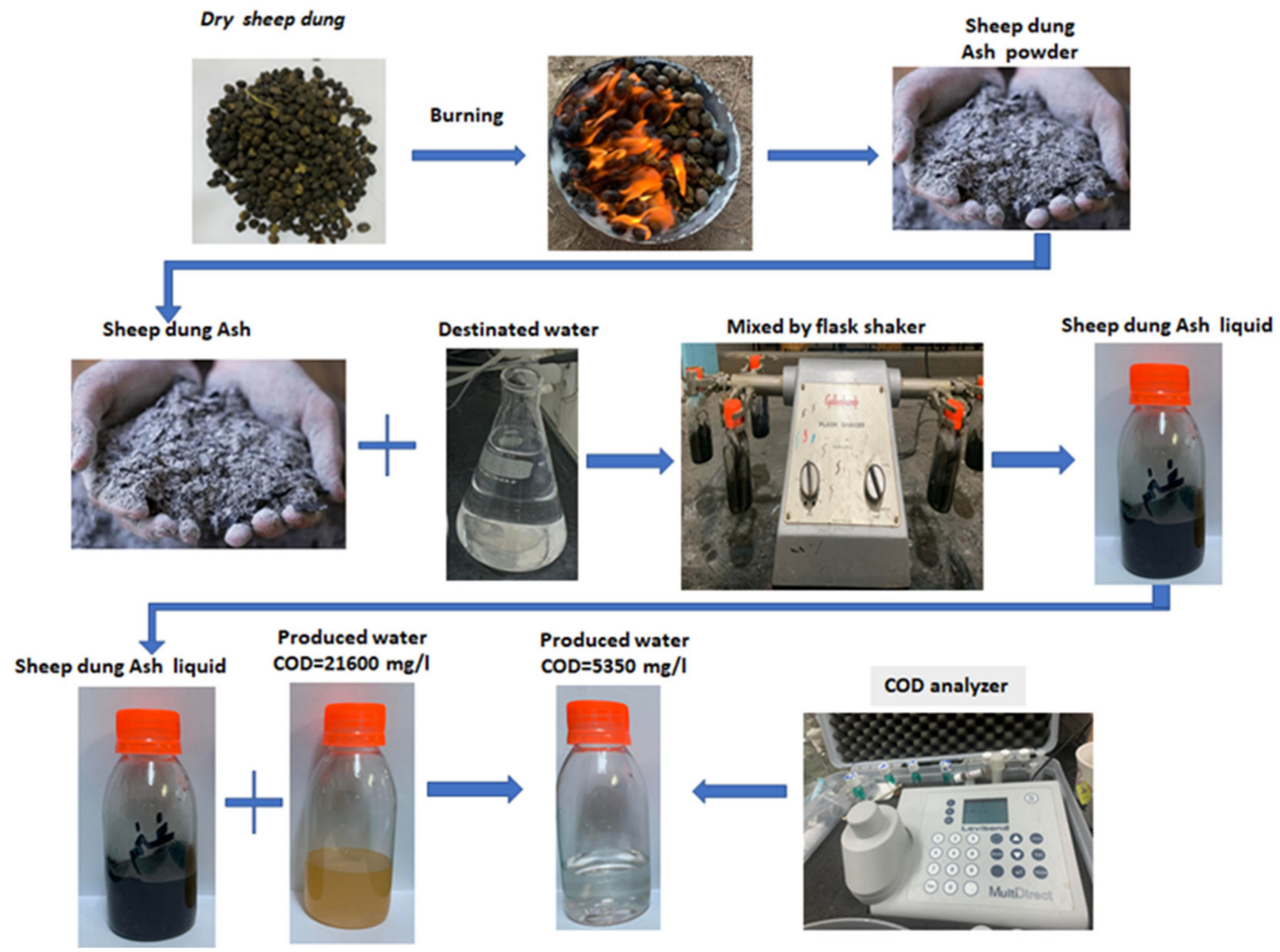

Figure 1. Schematic diagram of the experimental procedure in this study.

\subsection{Characterization of the Produced Ash}

FTIR spectra in the present study were recorded using a Magna-FT-IR 500 (Livonia, MI, USA) between 4000 and $300 \mathrm{~cm}^{-1}$, operating a Nicolet Omnic software and adopting the $\mathrm{KBr}$ disk technique. The scanning electron microscope used in this study is (SEM) JEOL JSM-IT 200 (Pleasanton, CA, USA). The EDXRF analyzer used in this study is a Jeol JSX-3222 element analyzer (Pleasanton, CA, USA) in the central laboratory at South Valley University. This analyzer is equipped with an $\mathrm{X}$-ray tube of a $\mathrm{Rh}$ anode and $\mathrm{Si}(\mathrm{Li})$ detector with an energy resolution of $149 \mathrm{eV}$ at $5.9 \mathrm{Kev}$ and $1000 \mathrm{cps}$.

\subsection{Adsorption Process}

The process of adsorption was carried out through a batch process by using a specified weight of the adsorbent in $50 \mathrm{~mL}$ of produced water of a known initial COD value. The water-ash mixtures were agitated for a specified contact time at $100 \mathrm{rpm}$ using a mechanical shaker. After adsorption, the mixture was filtered and the COD value of the filtrate was measured (Figure 1). In all cases, the values of the COD of the produced water were measured before and after the adsorption process and then the \% COD reduction was calculated as follows:

$$
\% \mathrm{COD} \text { reduction }=\left(\mathrm{COD}_{\mathrm{B}}-\mathrm{COD}_{\mathrm{A}}\right) \times 100 / \mathrm{COD}_{\mathrm{B}}
$$

Where $\mathrm{COD}_{\mathrm{B}}$ is the $\mathrm{COD}$ value of the produced water before starting the adsorption process and $\mathrm{COD}_{\mathrm{A}}$ is the $\mathrm{COD}$ value of the produced water after the adsorption process. The measurements of COD were carried out using a LOVIBOND Multicheckdirect filter- 
photometer (Dortmund, Germany) and the standard procedures of APHA 5220 D were followed.

\section{Results and Discussion}

\subsection{Adsorbent Characterization}

Figure 2 presents the EDX analysis of sheep dung ash, which shows high levels of oxygen, silicon, magnesium, and calcium, in addition to small proportions of aluminum, phosphorous, and potassium. The carbon signal in the spectrum likely originates from the sample support in addition to the unburned carbon.

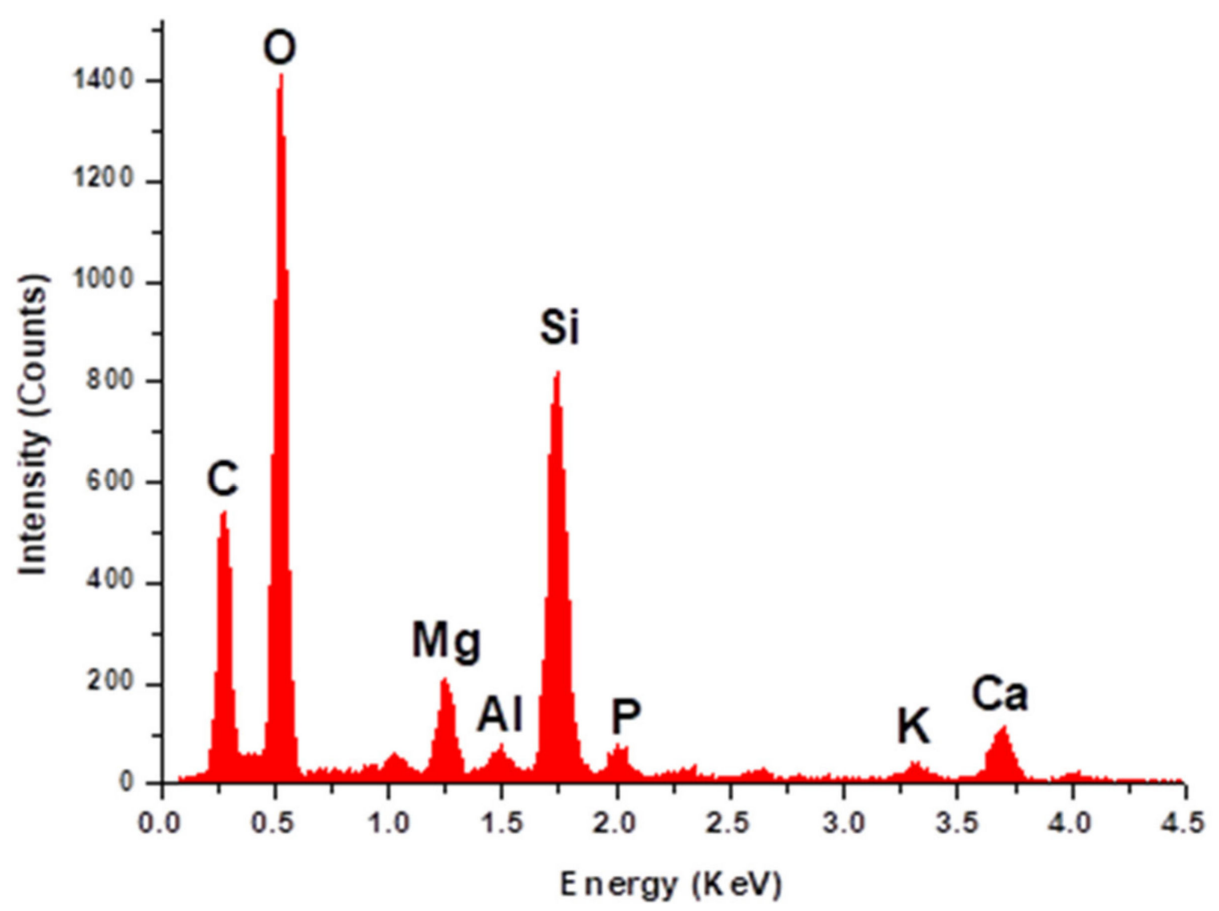

Figure 2. EDX analysis of sheep dung ash.

Figure 3 presents the sheep dung ash FTIR scan recorded between wavenumbers 4000 and $400 \mathrm{~cm}^{-1}$. The broad peak at $3433 \mathrm{~cm}^{-1}$ is related to the stretching vibration of the water $\mathrm{OH}$ group. The band at $1610 \mathrm{~cm}^{-1}$ is associated with the deformation vibration of the $\mathrm{H}-\mathrm{O}-\mathrm{H}$ group from the adsorbed water molecules [11-13]. The absorption bands at 1098, 798 , and $470 \mathrm{~cm}^{-1}$ are assigned to the asymmetric $\mathrm{Si}-\mathrm{O}-\mathrm{Si}$ stretch, the symmetric $\mathrm{Si}-\mathrm{O}-\mathrm{Si}$ stretch, and Si-O-Si deformation, respectively [14]. The bands at 875 and $1445 \mathrm{~cm}^{-1}$ are attributed to the presence of carbonate $\left(\mathrm{CO}_{3}{ }^{2-}\right)$ vibrations [15]. The bands in the 2365 and $2338 \mathrm{~cm}^{-1}$ range are attributed to the stretching of adsorbed $\mathrm{CO}_{2}[16,17]$. The $\mathrm{C}-\mathrm{H}$ bond stretches due to the $\mathrm{CH}_{2}-\mathrm{CO}$ group $[16,17]$. The bands at 2925 and $2855 \mathrm{~cm}^{-1}$ are assigned to the aliphatic $\mathrm{C}-\mathrm{H}$ stretching vibrations, suggesting that the sheep manure's direct burning could destroy organic material $[18,19]$.

The morphological structure of sheep dung ash was examined by SEM images, shown in Figure 4 at four different magnifications. As shown in Figure 4, the particles of sheep dung ash have an irregular structure and no visible crystalline phase or microspheres are seen. On magnification, the ash particles show a cellular structure that likely comes from plant material that was the primary food source of these animals, which depend on grazing as the primary food source. 


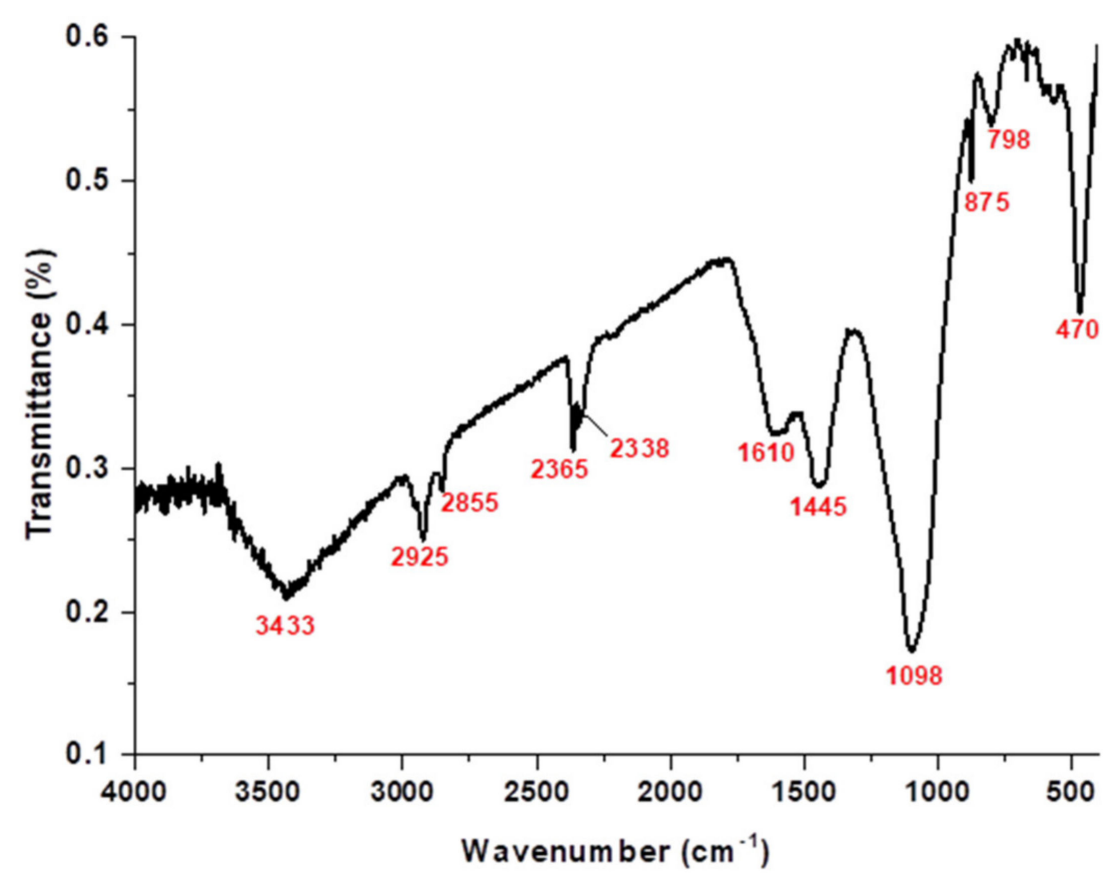

Figure 3. FTIR analysis of sheep dung ash.
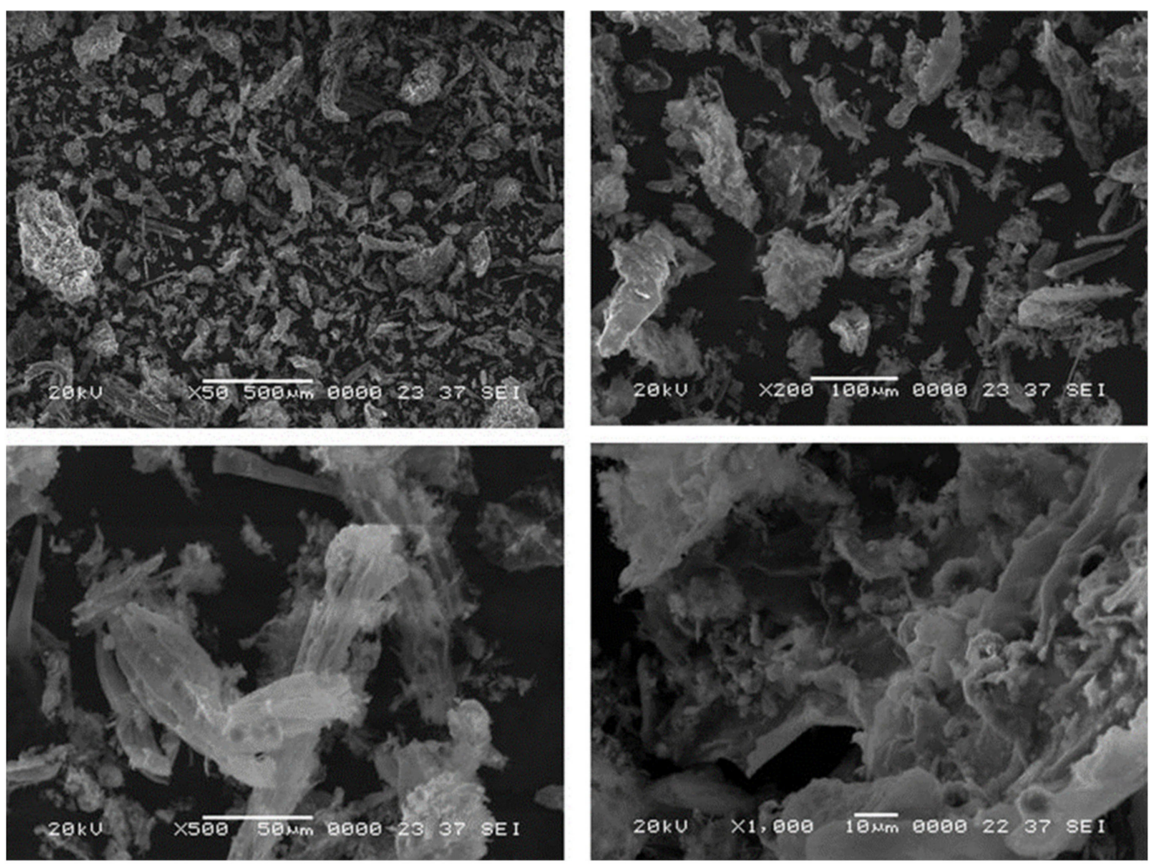

Figure 4. SEM images of sheep dung ash at different magnifications.

\subsection{Adsorption Process}

The physicochemical properties of the produced water used in this study are shown in Table 1. It is clear from the COD of the produced water that it is highly polluted with organic materials, making it one of the most dangerous sources of pollution if it is not treated before disposal or reuse. In general, the adsorption efficiency of solid adsorbents depends on some parameters that have an important role in the solid/liquid equilibrium, such as temperature, initial concentration of the adsorbate, contact time, $\mathrm{pH}$, and adsorbent dosage. The present work will study the effect of adsorbent dose, initial $\mathrm{pH}$ value, contact time, and initial COD value at room temperature. 
Table 1. Characteristics of produced water.

\begin{tabular}{ccc}
\hline Parameter & Unit & Value \\
\hline $\mathrm{pH}$ & - & 7.0 \\
Salinity & $\mathrm{mg} / \mathrm{L}$ & 205,335 \\
Hardness & $\mathrm{mg} / \mathrm{L}$ & 51,440 \\
Total Dissolved Solids & $\mathrm{mg} / \mathrm{L}$ & 227,400 \\
Chemical Oxygen Demand & $\mathrm{mg} / \mathrm{L}$ & 21,600 \\
Magnesium & $\mathrm{mg} / \mathrm{L}$ & 6676 \\
Calcium & $\mathrm{mg} / \mathrm{L}$ & 9620 \\
Chloride & $\mathrm{mg} / \mathrm{L}$ & 124,605 \\
Bicarbonate & $\mathrm{mg} / \mathrm{L}$ & 60 \\
\hline
\end{tabular}

\subsubsection{Effect of Adsorbent Dosage}

Figure 5a shows the values of \% COD removal as a function of adsorbent dosage, which varied from 10 to $50 \mathrm{~g} / \mathrm{L}$ at an initial COD value of 21,600 mg/L, a contact time of $1 \mathrm{~h}$, and an initial $\mathrm{pH}$ value of 7 . Figure $5 \mathrm{a}$ shows an increase in the \% COD reduction with the increase in the adsorbent dosage. The adsorption equilibrium is reached at an adsorbent dosage of $30 \% \mathrm{~g} / \mathrm{L}$, after which a relative stability in the \% COD removal is obtained. This increase in the \% COD reduction with the increase in the adsorbent dosage from 10 to $30 \mathrm{~g} / \mathrm{L}$ can be attributed to the increase in the number of active sites available for adsorption, which increases the ratio of surface-active sites to the COD causing molecules [8,14]. Then, the adsorption equilibrium is attained at an adsorbent dosage of $30 \mathrm{~g} / \mathrm{L}$ or higher. The observed partial decrease in the COD removal on increasing the adsorbent dosage to more than $30 \mathrm{~g} / \mathrm{L}$ is likely due to the aggregation resulting from high adsorbent doses, which would lead to a decrease in the total surface area of the adsorbent [20]. In all the subsequent adsorption experiments, the adsorbent dosage was kept at $30 \mathrm{~g} / \mathrm{L}$.
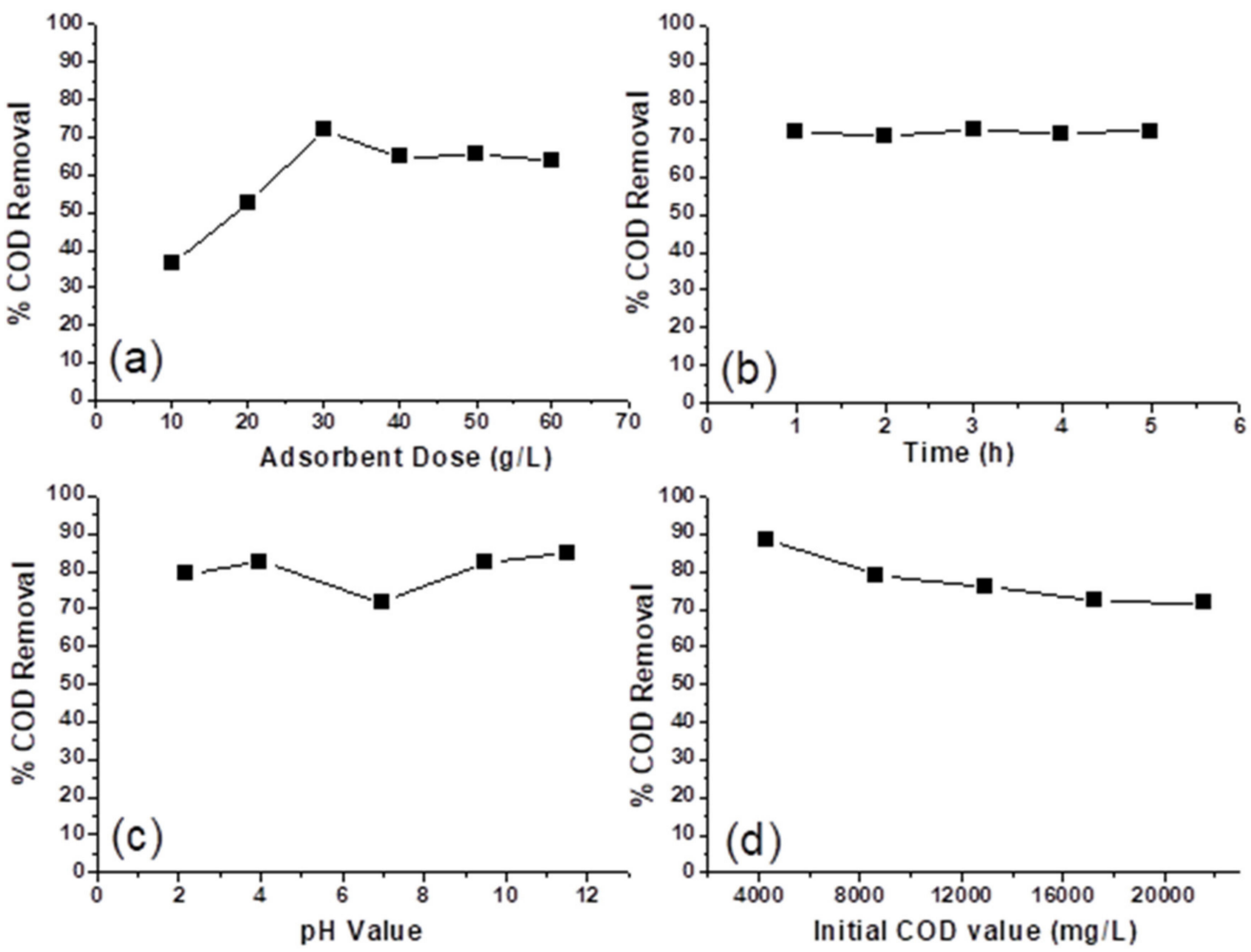

Figure 5. (a) Effect of adsorbent dose, (b) contact time, (c) initial $\mathrm{pH}$ value, and (d) initial COD value on the \% COD removal from PW by sheep dung ash as the adsorbent. 


\subsubsection{Effect of Contact Time}

The effect of increasing the contact time of PW with ash on the COD removal was studied and is presented in Figure $5 \mathrm{~b}$ as \% COD removal versus contact time, which was increased gradually from 1 to $5 \mathrm{~h}$. This experiment was carried out using produced water with an initial COD value of $21,600 \mathrm{mg} / \mathrm{L}$ and an adsorbent dosage of $30 \mathrm{~g} / \mathrm{L}$ at an initial $\mathrm{pH}$ value of 7 . It is clear from Figure $5 \mathrm{~b}$ that the optimum contact time is $\leq 1 \mathrm{~h}$, after which equilibrium was reached and the \% COD removal remained constant. The stable and independent nature of the \% COD removal/time relation line in Figure 5b indicates the formation of a monolayer cover of COD causing molecules on the adsorbent's outer surface in less than $1 \mathrm{~h}$, after which no more surface adsorption sites are available [21]. Thus, the equilibration contact time was kept at $1 \mathrm{~h}$ for all the subsequent adsorption experiments.

\subsubsection{Effect of Initial $\mathrm{pH}$ Value}

The effect of produced water's initial $\mathrm{pH}$ value on the COD removal efficiency of sheep ash is shown in Figure 5c. The importance of solution $\mathrm{pH}$ comes from its effect on the charge of the adsorbent surface, the adsorbent's degree of ionization, and the functional groups' dissociation on the active sites of the adsorbent [14]. The initial $\mathrm{pH}$ values used are $2.2,4,7,9.5$, and 11.5 at an initial COD value of $21,600 \mathrm{mg} / \mathrm{L}$, an adsorbent dosage of $30 \mathrm{~g} / \mathrm{L}$, and a contact time of $1 \mathrm{~h}$. It can be seen from Figure $5 \mathrm{c}$ that the \% COD removal is higher to some extent when the $\mathrm{pH}$ is below or above 7 , which is likely due to the presence of more than one adsorption mechanism between the COD causing organic molecules and the adsorbent surface. A similar observation was reported by [14] during the study of using activated carbon as an adsorbent to remove COD from leachate containing about 27 different organic pollutants. They found that the removal rate of COD is higher when the $\mathrm{pH}$ is below or above 7 . They correlated this behavior to the presence of more than one mechanism between COD causing organic compounds in the leachate and the carbon surface. Furthermore, the same effect of $\mathrm{pH}$ on COD removal efficiency was reported by Khurshid and his co-workers [4] during their study of the adsorptive removal of COD from produced water using tea waste biochar. They found that the removal efficiency was minimum at $\mathrm{pH} 6$ and increased with increasing and decreasing $\mathrm{pH}$ values.

\subsubsection{Effect of Initial COD Value}

Figure $5 \mathrm{~d}$ shows the values of $\%$ COD removal as a function of the initial COD value. The effect of the initial COD value of PW on the COD removal efficiency was studied at a contact time of $1 \mathrm{~h}$ and an adsorbent dosage of $30 \mathrm{~g} / \mathrm{L}$ at the initial solution $\mathrm{pH}$ value of 7. The PW samples' different COD values were obtained by diluting the original PW sample $(21,600 \mathrm{mg} / \mathrm{L})$ using deionized water. As shown in Figure $5 \mathrm{~d}$, by increasing the initial COD concentration from 4320 to $21,600 \mathrm{mg} / \mathrm{L}$, the $\%$ COD removal decreased from 88.4 to $71.7 \%$. This is likely because, at low COD values, the ratio of surface-active sites to the COD causing organic molecules in water is high. Hence, all COD causing molecules may interact with the active sites on the ash surface [4]. By increasing the initial COD value, the ratio of surface-active sites to the COD molecules will decrease so that the \% COD removal will decrease. To make treating produced water with sheep dung ash easier and less expensive, especially if it is applied on a large scale, the adsorption experiment was carried out without shaking, see Figure 6 . The considerably long time required to attain the adsorption equilibrium without shaking can be attributed to the absence of the kinetic energy of the particles of adsorbent and the COD molecules. Shaking the mixtures increases this kinetic energy and increases the chances of adsorbent particles to interact with COD molecules [22]. 


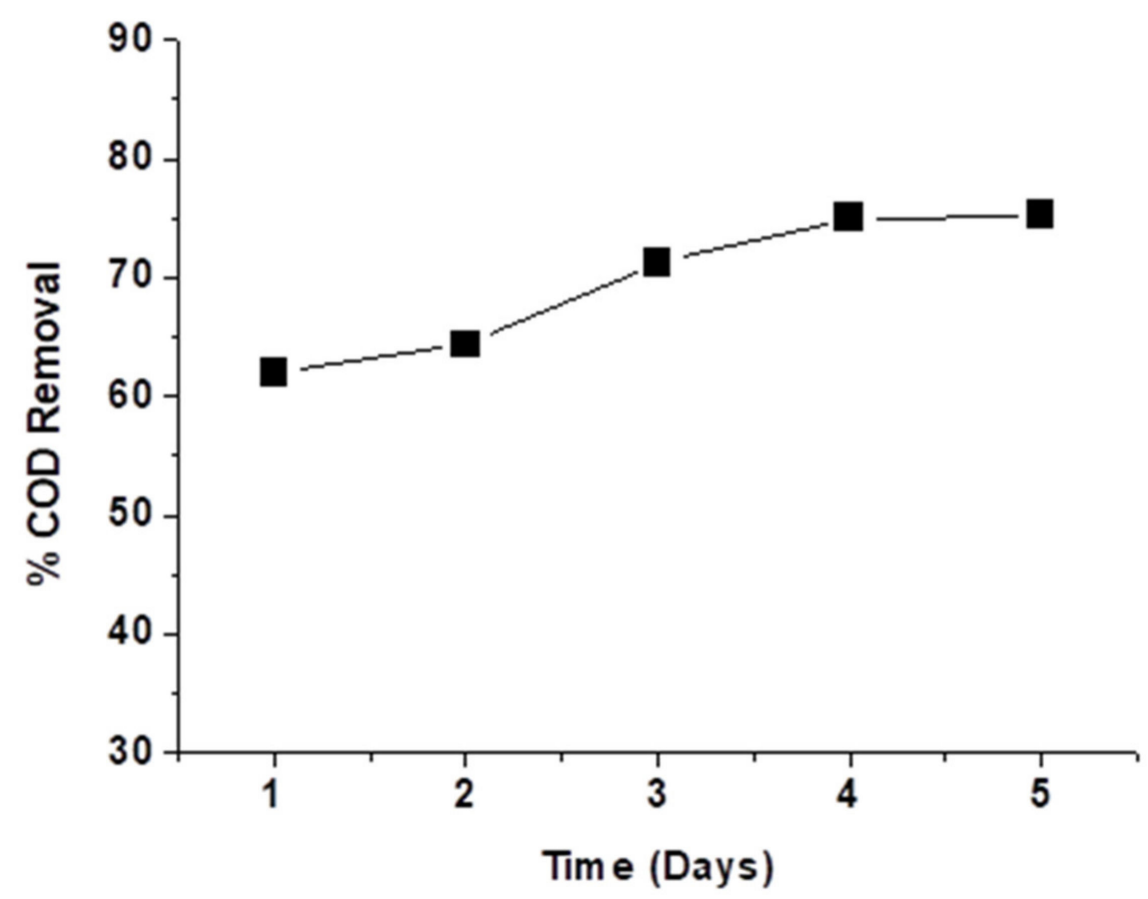

Figure 6. Effect of contact time in days on the \% COD removal from PW by sheep dung ash as adsorbent (without shaking of the mixture).

\subsection{Adsorption Isotherms}

The adsorption isotherms are valuable curves to study the adsorption equilibrium and provide important information about the interaction between adsorbent and adsorbate during the adsorption process. The adsorption isotherm is a $Y$-against- $\mathrm{X}$ graph, where $\mathrm{Y}$ is the amount of adsorbate on the adsorbent surface and $X$ is the adsorbate's concentration (or pressure) at a constant temperature [20]. In the case of produced water, which is considered as multi-component system, Langmuir and Freundlich isotherm models are the most suitable [8]. According to the Langmuir model, the adsorption occurs at a specific site to form a monolayer of the adsorbate over the adsorbent's homogenous surface. The Langmuir isotherm has the linear form shown in Equation (2) [20]:

$$
\mathrm{C}_{\mathrm{e}} / \mathrm{q}_{\mathrm{e}}=\left(1 / \mathrm{bQ} \mathrm{Q}_{\mathrm{m}}\right)+\left(\mathrm{C}_{\mathrm{e}} / \mathrm{Q}_{\mathrm{m}}\right)
$$

where $\mathrm{q}_{\mathrm{e}}(\mathrm{mg} / \mathrm{g})$ is the amount of adsorbate per unit weight of adsorbent at equilibrium, $\mathrm{C}_{\mathrm{e}}(\mathrm{mg} / \mathrm{L})$ is the equilibrium concentration of adsorbate, $\mathrm{Q}_{\mathrm{m}}(\mathrm{mg} / \mathrm{g})$ is the maximum adsorption capacity of the adsorbate by the adsorbent, and b is a constant related to adsorption enthalpy and represents a measure of the binding energy of adsorbate to the adsorbent. By plotting $C_{e} / q_{e}$ as a function of $C_{e}$, the values of $b$ and $Q_{m}$ can be obtained from the slope and the intercept. According to the Freundlich model, monolayer or multilayer adsorbate molecules are formed on the adsorbent's heterogeneous surface [21]. The Freundlich isotherm has the linear form shown in Equation (3) [22]:

$$
\log q_{e}=\log \mathrm{K}_{\mathrm{f}}+(1 / n) \log \mathrm{C}_{\mathrm{e}}
$$

where $\mathrm{K}_{\mathrm{f}}$ is a constant related to adsorption capacity and $n$ is a constant related to adsorption intensity. By plotting $\log q$ e against $\log \mathrm{C}_{\mathrm{e}}$, the values of $n$ and $\mathrm{K}_{\mathrm{f}}$ can be calculated from the slope and the intercept, respectively.

The experimental results obtained in this study were applied to Langmuir and Freundlich models to select the model that describes sheep ash's adsorption process. The correlation coefficient $\left(\mathrm{R}^{2}\right)$ can be used to evaluate the applicability of the used isotherms $[21,22]$. The linearized isotherms of both Langmuir and Freundlich models at room temperature 
are shown in Figure 7. In addition, Table 2 shows the Langmuir and Freundlich isotherm parameters for the adsorption of COD causing molecules onto sheep dung ash.
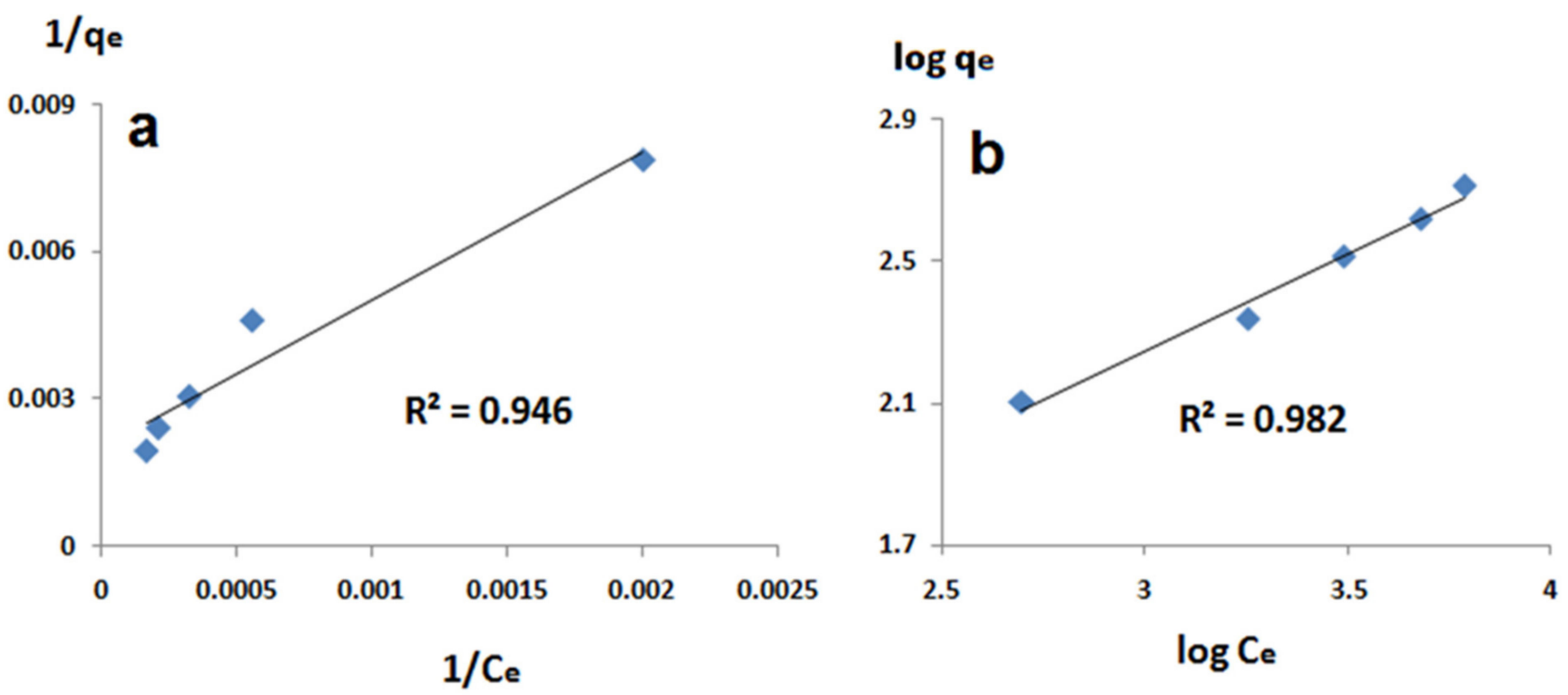

Figure 7. Linearized adsorption isotherms: (a) Langmuir isotherm and (b) Freundlich isotherm of sheep dung ash.

Depending on the correlation coefficient $\left(\mathrm{R}^{2}\right)$ values, both Langmuir and Freundlich models can describe the adsorption process with better correlation to the Freundlich isotherm model. A similar result was obtained during a previous study [8], in which we used boehmite nanopowder and commercial activated carbon as solid adsorbents to reduce PW's COD. We found that the adsorption process follows both Langmuir and Freundlich models both in the case of boehmite and commercial activated carbon. This was explained as a result of the nature of PW, a multi-component system containing many different components with different properties. From Table 2, we can see that the value of the Freundlich constant $(n)$ is lower than 10 and higher than 1 , indicating that the COD adsorption process is favorable to sheep dung ash [20,23-25].

Table 2. Parameters of Langmuir and Freundlich isotherms for COD adsorption onto sheep dung ash.

\begin{tabular}{cccccc}
\hline \multicolumn{3}{c}{ Langmuir Model } & \multicolumn{3}{c}{ Freundlich Model } \\
\hline $\mathrm{KL}(\mathrm{L} / \mathrm{mg})$ & $\mathrm{q}_{\mathrm{m}}(\mathrm{mg} / \mathrm{g})$ & $\mathrm{R}^{2}$ & $n$ & $\mathrm{~K}_{\mathrm{f}}$ & $\mathrm{R}^{2}$ \\
0.00066 & 500 & 0.946 & 1.8 & 3.8 & 0.982 \\
\hline
\end{tabular}

A comparison between the efficiency of sheep dung ash in the adsorption of COD and that of some other adsorbents and techniques reported in the literature is presented in Table 3. Considering the high value of the COD of the produced water used in this study and the meagre cost of adsorbent preparation and adsorption operation, one can see that the adsorption of COD on sheep dung ash is a robust competitor technology that can be used mainly in developing countries. 
Table 3. Comparison of COD removal efficiency of sheep dung ash with that of some other adsorbents and techniques in the literature.

\begin{tabular}{|c|c|c|c|}
\hline Technique Used for COD Adsorption & Initial COD Value (mg/L) & $\%$ COD Removal & References \\
\hline Adsorption on sheep dung ash & 21,600 & 75 & This study \\
\hline Photoelectrocatalysis on a coil-type microreactor & 9500 & 81 & [1] \\
\hline Adsorption on tea waste biochar & 2400 & 89.4 & [4] \\
\hline Adsorption on powdered activated carbon & 2508 & 95.9 & [5] \\
\hline Adsorption on clinoptilolite natural zeolite & 2508 & 63.7 & [5] \\
\hline Adsorption on boehmite nanopowder & 1150 & 69.6 & [8] \\
\hline Adsorption on commercial activated carbon & 1150 & 83.5 & [8] \\
\hline Activated cow dung ash & 2600 & 79 & [8] \\
\hline Electro-oxidation & 7150 & 97 & [26] \\
\hline Electro-coagulation using an Fe electrode & 355 & 70.09 & [27] \\
\hline Photoelectrocatalysis using a hybrid Ca-Fe-LDH catalyst & 1830 & 99 & [28] \\
\hline Fixed-film sequencing batch reactor & 26,133 & 74.43 & [29] \\
\hline $\begin{array}{l}\text { Electrochemical oxidation with } \mathrm{IrO}_{2}-\mathrm{Ta}_{2} \mathrm{O}_{5} / \mathrm{Ti} \text { anodes and } \\
\text { chitosan powder }\end{array}$ & 55,000 & 94 & [30] \\
\hline Fenton-alternating current electro-coagulation & 1000 & 94.21 & [31] \\
\hline Adsorption on fly ash & 1080 & 87.84 & [32] \\
\hline Coagulation using titanium and zirconium salts & 3020 & 69.33 & [33] \\
\hline Electro-coagulation & 448 & 97.02 & [34] \\
\hline $\begin{array}{l}\text { Hybrid methodology (i.e., combined rotavapor distillation, } \\
\text { Fenton, and anerobic biological treatment) }\end{array}$ & 90,000 & 95 & [35] \\
\hline UV-electroproxone procedure & 9433 & 83 & [36] \\
\hline
\end{tabular}

\section{Conclusions}

Sheep dung ash was prepared using a costless preparation process by burning it with a direct flame to simulate the method used in rural areas worldwide. The produced ash was used as a low-cost, available, renewable, and effective solid adsorbent to treat oilfieldproduced water of high organic pollution levels using a straightforward treatment and a cost-effective operation process. The sheep dung ash shows high efficiency in removing COD from produced water, with a maximum COD removal of $71.8 \%$ after $1 \mathrm{~h}$ in the case of shaking the mixture and that of $75 \%$ after 4 days without shaking. Sheep dung ash represents a promising low-cost adsorbent for treating highly polluted oilfield-produced water using a process with a straightforward and costless operation. Sheep dung ash can replace many expensive adsorbent or complicated techniques, especially in developing countries.

Author Contributions: A.M.A. and A.A. conceived the original idea, performed the analytic calculations, and took the lead in writing the manuscript; A.M.A., A.A. and S.M.A. performed the methodology; A.M.A. and A.A. reviewed the manuscript, provided critical feedback, aided in interpreting the results, and helped shape the manuscript. All authors have read and agreed to the published version of the manuscript.

Funding: The authors extend their appreciation to the Deanship of Scientific Research at the King Khalid University for funding this work through the Research Group Project under grant number (RGP. 2/92/43).

Institutional Review Board Statement: Not applicable.

Informed Consent Statement: Not applicable.

Data Availability Statement: Not applicable. 
Acknowledgments: The authors would like to express their gratitude to the King Khalid University, Saudi Arabia for providing administrative and technical support.

Conflicts of Interest: The authors declare no conflict of interest.

\section{References}

1. Ebadi, S.; Ghasemipanah, K.; Alaie, E.; Rashidi, A.; Khataee, A. COD removal from gasfield produced water using photoelectrocatalysis process on coil type microreactor. J. Ind. Eng. Chem. 2021, 98, 262-269. [CrossRef]

2. Al-Ghouti, M.A.; Al-Kaabi, M.A.; Ashfaq, M.Y.; Da'na, D.A. Produced water characteristics, treatment and reuse: A review. J. Water Process Eng. 2019, 28, 222-239. [CrossRef]

3. Liu, Y.; Lu, H.; Li, Y.; Xu, H.; Pan, Z.; Dai, P.; Wang, H.; Yang, Q. A review of treatment technologies for produced water in offshore oil and gas fields. Sci. Total Environ. 2021, 775, 145485. [CrossRef] [PubMed]

4. Khurshid, H.; Mustafa, M.R.U.; Rashid, U.; Isa, M.H.; Ho, Y.C.; Shah, M.M. Adsorptive removal of COD from produced water using tea waste biochar. Environ. Technol. Innov. 2021, 23, 101563. [CrossRef]

5. Khader, E.H.; Mohammed, T.J.; Mirghaffari, N.; Salman, A.D.; Juzsakova, T.; Abdullah, T.A. Removal of organic pollutants from produced water by batch adsorption treatment. Clean Technol. Environ. Policy 2021, 1, 1-8. [CrossRef]

6. Udeagbara, S.G.; Isehunwa, S.O.; Okereke, N.U.; Oguamah, I.U. Treatment of produced water from Niger Delta oil fields using simultaneous mixture of local materials. J. Pet. Explor. Prod. 2021, 11, 289-302. [CrossRef]

7. Dos Santos, E.V.; Bezerra Rocha, J.H.; de Araújo, D.M.; de Moura, D.C.; Martínez-Huitle, C.A. Decontamination of produced water containing petroleum hydrocarbons by electrochemical methods: A minireview. Environ. Sci. Pollut. Res. 2014, 21, 8432-8441. [CrossRef] [PubMed]

8. Abdelkader, A.; Hussien, B.M.; Fawzy, E.M.; Ibrahim, A.A. Boehmite nanopowder recovered from aluminum cans waste as a potential adsorbent for the treatment of oilfield produced water. Appl. Petrochem. Res. 2021, 11, 137-146. [CrossRef]

9. Kaur, K.; Mor, S.; Ravindra, K. Removal of chemical oxygen demand from landfill leachate using cow-dung ash as a low-cost adsorbent. J. Colloid Interface Sci. 2016, 469, 338-343. [CrossRef]

10. Dorge, S.; Jeguirim, M.; Trouvé, G. Thermal degradation of Miscanthus pellets: Kinetics and aerosols characterization. Waste Biomass Valorization 2011, 2, 149-155. [CrossRef]

11. Ojeme, V.C.; Ayodele, O.; Oluwasina, O.O.; Okoronkwo, E.A. Adsorption of $\mathrm{Pb}(\mathrm{II})$ ions from aqueous solutions using chemically treated and untreated cow dung ash. BioResources 2019, 14, 2622-2641.

12. Kalembkiewicz, J.; Galas, D.; Sitarz-Palczak, E. The physicochemical properties and composition of biomass ash and evaluating directions of its applications. Pol. J. Environ. Stud. 2018, 27, 2593-2604. [CrossRef]

13. Parande, A.K.; Stalin, K.; Thangarajan, R.K.; Karthikeyan, M.S. Utilization of Agroresidual Waste in Effective Blending in Portland Cement. ISRN Civ. Eng. 2011, 2011, 1-12. [CrossRef]

14. He, Y.; Liao, X.; Liao, L.; Shu, W. Low-cost adsorbent prepared from sewage sludge and corn stalk for the removal of COD in leachate. Environ. Sci. Pollut. Res. 2014, 21, 8157-8166. [CrossRef]

15. Vaiciukyniene, D.; Nizeviciene, D.; Mikelioniene, A.; Radzevicius, A. Utilization of zeolitic waste in alkali-activated biomass bottom ash blends. Molecules 2020, 25, 3053. [CrossRef]

16. Nagalakshmi, T.V.; Emmanuel, K.A.; Suresh Babu, C.; Chakrapani, C.; Divakar, P.P. Preparation of Mesoporous Activated Carbon from Jackfruit PPI-1 Waste and Development of Different Surface Functional Groups. Int. Lett. Chem. Phys. Astron. 2015, 54, 189-200. [CrossRef]

17. Galhotra, P.; Navea, J.G.; Larsen, S.C.; Grassian, V.H. Carbon dioxide $\left(\mathrm{C}_{16} \mathrm{O}_{2}\right.$ and $\left.\mathrm{C}_{18} \mathrm{O}_{2}\right)$ adsorption in zeolite y materials: Effect of cation, adsorbed water and particle size. Energy Environ. Sci. 2009, 2, 401-409. [CrossRef]

18. Pasela, B.R.; Castillo, A.P.; Simon, R.; Pulido, M.T.; Mana-ay, H.; Abiquibil, M.R.; Montecillo, R.; Thumanu, K.; von Tumacder, D.; Taaca, K.L. Synthesis and characterization of acetic acid-doped polyaniline and polyaniline-chitosan composite. Biomimetics 2019, 4, 15. [CrossRef]

19. Liang, X.; Jin, Y.; He, M.; Niyungeko, C.; Zhang, J.; Liu, C.; Tian, G.; Arai, Y. Phosphorus speciation and release kinetics of swine manure biochar under various pyrolysis temperatures. Environ. Sci. Pollut. Res. 2018, 25, 25780-25788. [CrossRef]

20. Baseri, H.; Tizro, S. Treatment of nickel ions from contaminated water by magnetite based nanocomposite adsorbents: Effects of thermodynamic and kinetic parameters and modeling with Langmuir and Freundlich isotherms. Process Saf. Environ. Prot. 2017, 109, 465-477. [CrossRef]

21. Nayl, A.A.; Elkhashab, R.A.; El Malah, T.; Sobhy, M.; Yakout, S.M.; El-Khateeb, M.A.; Ali, M.M.S.; Ali, H.M. Adsorption studies on the removal of COD and BOD from treated sewage using activated carbon prepared from date palm waste. Environ. Sci. Pollut. Res. 2017, 24, 22284-22293. [CrossRef]

22. Jamil, N.; Khan, S.M.; Ahsan, N.; Anwar, J.; Abdul, Q.; Zameer, M.; Shafique, U. Removal of Direct Red 16 (Textile Dye) from Industrial Effluent by using Feldspar. J. Chem. Soc. Pak. 2014, 36, 191-197.

23. Bhatnagar, A.; Jain, A.K.; Mukul, M.K. Removal of congo red dye from water using carbon slurry waste. Environ. Chem. Lett. 2005, 2, 199-202. [CrossRef] 
24. Gallo-Cordova, A.; Silva-Gordillo, M.D.M.; Muñoz, G.A.; Arboleda-Faini, X.; Almeida Streitwieser, D. Comparison of the adsorption capacity of organic compounds present in produced water with commercially obtained walnut shell and residual biomass. J. Environ. Chem. Eng. 2017, 5, 4041-4050. [CrossRef]

25. Wang, W.; Wang, J. Comparative evaluation of sorption kinetics and isotherms of pyrene onto microplastics. Chemosphere 2018, 193, 567-573. [CrossRef] [PubMed]

26. Veli, S.; Arslan, A.; Isgoren, M.; Bingöl, D.; Demiral, D. Experimental design approach to COD and color removal of landfill leachate by the electrooxidation process. Environ. Chall. 2021, 5, 100369. [CrossRef]

27. Bajpai, M.; Katoch, S.S. Reduction of COD from real graywater by electro-coagulation using Fe electrode: Optimization through box-behnken design. Mater. Today Proc. 2020, 43, 303-307. [CrossRef]

28. Oladipo, A.A. $\mathrm{CuCr}_{2} \mathrm{O}_{4} @ \mathrm{CaFe}-\mathrm{LDO}$ photocatalyst for remarkable removal of COD from high-strength olive mill wastewater. $J$. Colloid Interface Sci. 2021, 591, 193-202. [CrossRef]

29. Potivichayanon, S.; Toensakes, R.; Supromin, N.; Seaung, K. Removal of High Levels of Cyanide and COD from Cassava Industrial Wastewater by a Fixed-Film Sequencing Batch Reactor. Water Air. Soil Pollut. 2020, 231, 301. [CrossRef]

30. Myburgh, D.P.; Aziz, M.; Roman, F.; Jardim, J.; Chakawa, S. Removal of COD from Industrial Biodiesel Wastewater Using an Integrated Process: Electrochemical-Oxidation with $\mathrm{IrO}_{2}-\mathrm{Ta}_{2} \mathrm{O}_{5} / \mathrm{Ti}$ Anodes and Chitosan Powder as an Adsorbent. Environ. Process. 2019, 6, 819-840. [CrossRef]

31. Kong, X.; Zhou, Y.; Xu, T.; Hu, B.; Lei, X.; Chen, H.; Yu, G. A novel technique of COD removal from electroplating wastewater by Fenton-alternating current electrocoagulation. Environ. Sci. Pollut. Res. 2020, 27, 15198-15210. [CrossRef]

32. Devi, R.; Dahiya, R.P. Chemical oxygen demand (COD) reduction in domestic wastewater by fly ash and brick kiln ash. Water Air Soil Pollut. 2006, 174, 33-46. [CrossRef]

33. Uysal, A.; Boyacioglu, E. Evaluation of the performance of titanium and zirconium salts as coagulants in industrial wastewater treatment: Pollutant removal, sludge production, and sludge characteristics. Appl. Water Sci. 2021, 11, 78. [CrossRef]

34. Ebba, M.; Asaithambi, P.; Alemayehu, E. Investigation on operating parameters and cost using an electrocoagulation process for wastewater treatment. Appl. Water Sci. 2021, 11, 175. [CrossRef]

35. Akinapally, S.; Dheeravath, B.; Panga, K.K.; Vurimindi, H.; Sanaga, S. Treatment of pesticide intermediate industrial wastewater using hybrid methodologies. Appl. Water Sci. 2021, 11, 56. [CrossRef]

36. Kermani, M.; Shahsavani, A.; Ghaderi, P.; Kasaee, P.; Mehralipour, J. Optimization of UV-Electroproxone procedure for treatment of landfill leachate: The study of energy consumption. J. Environ. Health Sci. Eng. 2021, 19, 81-93. [CrossRef] 